lumen of the endoplasmic reticulum during synthesis. His targets are the pope in this case, George Palade - and his supporters. The aim of this book is not to defrock anyone; rather, it is to make cell biologists realize that, although vesicles and membrane compartments exist and contain particular components, they are not the transient balloons that people imagine.

Rothman concludes from his own work that the secretory granules found in pancreas are most likely permanent bodies, through whose membranes the contents can diffuse in a regulated fashion. Thus, he argues, the granule contents, including trypsinogen, chymotrypsinogen and amylase, are released from the pancreatic cell by diffusing across the granule membrane into the cytoplasm and, from there, diffusing across the plasma membrane into the extracellular spaces. In other words, the regulated release of proteins from cells is effected by modifying the permeability of these membranes to the secreted proteins, but only to those proteins. Membrane fusion, whereby extracytoplasmic compartments may be joined together, he would like to suggest, is a cell biologist's fantasy. So far, this review must have sounded like music to Rothman's ears, but this is where the music ends.

The first half of the book is concerned with expounding the vesicle model and poking holes in the evidence for it, softening up the reader for the second round. Here, experiments from Rothman's laboratory, carried out over the past 20 years, are described and interpreted: in terpreted within the frameworks of his model, which is "simple, physical diffusion", and of the vesicle paradigm involving fusion, which always requires extra ad hoc addenda to explain his own experiments and which, to his way of thinking, is unnecessarily complicated. I am afraid it isn't worth discussing the arguments further - an interested reader may wish to look at the evidence. Suffice it to say that Rothman's whole approach is nonmolecular; his own experiments are, as he admits in a footnote, sometimes unreliable (p.191); he ignores facts, such as the existence of a glycosylation pathway for secreted proteins and that cytoplasmic proteins are never glycosylated. Moreover, he does not even mention the whole field of endocytosis, which, better than any other, has clearly demonstrated that membrane fusion must occur, and that membrane which goes in does usually come out during exocytosis.

When I go into the booth to vote, I'll spoil my ballot. I care neither for this book, nor for the unquestioning assumption that the majority is always right.

M.S. Bretscher is Joint Head of the Cell Biology Division in the Medical Research Council Laboratory of Molecular Biology, Hills Road, Cambridge CB2 $2 Q H$, UK.

\title{
Cellular renewal
}

\section{David M. Prescott}

Molecular Cytology. Vol 1 The Cell Cycle. Vol 2 Cell Interactions. By Jean Brachet. Academic: 1986. Vol. 1 pp. 424, hbk $\$ 59.50, £ 52 ; p b k \$ 34.95$, £31. Vol. 2 pp. $512, h b k \$ 73, £ 60 ; p b k \$ 42, £ 35$.

Professor Jean Brachet's earlier book, Biochemical Cytology, was published in 1957 and it is more than likely that younger researchers in cell biology have never come across it. In its time it was an exciting book that formalized the new, developing way of thinking about cells; cytology fused with biochemistry could produce new insight and understanding about cell structure and function. Contemporary biologists can hardly imagine anything other than such an integrated approach to the cell, but that was not always the case.

Between 1835 and 1957, less than 100 research papers were published on what is now called the cell cycle of prokaryotes and eukaryotes (excluding the mechanism of mitosis). In 1985 , over 100 research papers on the cell cycle were published every week. In 1957, a scientist could remain well informed about essentially all phases of what is now called cell biology with a few hours a week in the library; indeed, the term cell biology had then not yet been invented and the Journal of Cell Biology was still called the Journal of Biophysical and Biochemical Cytology.

The two volumes of Molecular Cytology are a second edition of Biochemical Cytology, published now 28 years after the first edition. As in the first edition, the author's aim is "to present a critical and synthetic view" of the biochemical basis of cell structure and function. The view is unmistakably that of a biologist who sees biochemistry as a resource for understanding what cells do. Volume I has the subtitle The Cell Cycle but only the last 125 pages deal with this subject. The remaining pages are devoted to techniques in cell biology, the cytoskeleton, the plasma membrane, cytoplasmic organelles, chromatin organization, the nucleolus and a few other things. Volume II is subtitled Cell Interactions. That means nucleocytoplasmic interactions in unicellular organisms, in somatic cells and in oocytes. But the middle part of the volume is about cleavage, embryonic determination and early development, and the last part discusses differentiation, cell transformation (cancer) and cell ageing. In both books the writing is incisive, and the information is up to date and well referenced.

The author says in the preface that the volumes are intended for advanced students and researchers; that seems about right. The level and style of writing is somewhere between that found in the
Annual Reviews series and the textbook Molecular Biology of the Cell by Alberts et al. The discussions are enhanced by the author's historical perspective, some of it the fruit of personal experience. History in science doesn't appeal to everyone, especially not to the young. It's a taste acquired as one becomes a part of history.

The coverage of material in these two volumes is a remarkable accomplishment for a single individual; it represents many years' accumulation of knowledge and provides the reader with an integrated view that multi-authored books never achieve. No book is ever perfect, and these volumes have their imperfections. Much more is known about the causes of cell transformation (cancer) than the author states; amitosis is not "an agonic phenomenon" but alive and well in ciliated protozoa; and G1 of the cell cycle is not generally assumed to be a period of accumulation of machinery required for DNA synthesis.

Overall, however, the two volumes achieve their purpose. There is little in them that I could disagree with and they are worth the attention of students and researchers. I expect to refer to them regularly for some years to come.

David M. Prescott is Distinguished Professor in the Department of Molecular, Cellular and Developmental Biology, University of Colorado, Boulder, Colorado 80309-0347, USA.

\section{THE MANAGEMENT OF AIDS PATIENTS \\ Edited by DAVID MILLER, \\ JONATHAN WEBER and JOHN GREEN}

The Management of AIDS Patients is the first comprehensive guide to the practical clinical management of patients with AIDS or HTLV III infections. The book avoids the sensational aspects of the disease, offering solid advice and information for all people involved in patient care.

The editors and many of the contributors come from St Mary's Hospital, London one of the foremost centres in Britain for the treatment of AIDS patients. The knowledge and experience of these experts has been combined to provide a much-needed book for doctors, nurses, dentists and indeed for health-care professionals everywhere.

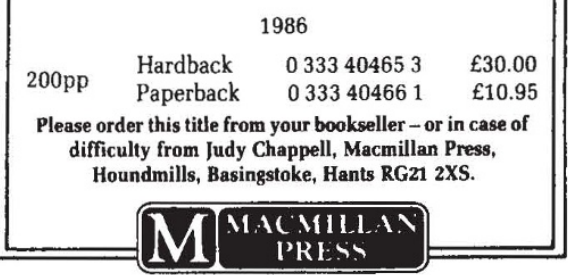

